\title{
ПРОБЛЕМЫ СТАРЕНИЯ НАСЕЛЕНИЯ И ИХ ПРИОРИТЕТНАЯ ПОЗИЦИЯ В ПЕРЕЧНЕ ПРОБЛЕМ НАСТОЯЩЕГО ВРЕМЕНИ РАЗВИТИЯ ОБЩЕСТВА *
}

\author{
(c) 2020 Петров A.M.
}

доктор экономических наук, профессор Департамента бизнес-аналитики

Финансовый университет при Правительстве Российской Федерации, Россия, Москва

E-mail:palmi@inbox.ru

(c) 2020 Антонова 0.В.

кандидат экономических наук, доцент Департамента бизнес-аналитики

Финансовый университет при Правительстве Российской Федерации, Россия, Москва

E-mail: olgavit01@yandex.ru

(c) 2020 Мустафаева С.P.

менеджер Департамента бизнес-аналитики

Финансовый университет при Правительстве Российской Федерации, Россия, Москва

E-mail: SRMustafaeva@fa.ru

Сегодня практически все страны мира столкнулись с проблемой демографического дисбаланса вследствие демографического старения населения. Демографическое старение - это увеличение численности лиц пожилого возраста на фоне снижения числа лиц трудоспособного возраста планеты. Процесс демографического старения является естественным процессом. Ему подвержены все страны мирового пространства. Процесс демографического старения негативно влияет на рождаемость, что обуславливает старение общества снизу. В свою очередь демографическое старение повышает средний возраст населения и обуславливается процессом старения общества сверху.

Демографическое старение наблюдается в европейских странах, в Российской Федерации, США, Канаде, Японии, Азии, странах Латинской Америки. Постарение население наблюдается и в Австралии, Новой Зеландии. Процесс постарения населения обуславливается процессом старения общества сверху, что указывает на увеличения населения старше трудоспособного возраста.

Проблема омоложения нации беспокоит многие передовые страны. Таким образом, в современном мире проблемы постарения населения занимают приоритетную позицию в перечне проблем настоящего времени развития общества мирового пространства. Являясь наиболее крупной общественной трансформацией нашего столетия, оказывающей влияние на экономики различных стран, систему здравоохранения, а также и социального обеспечения, постарение населения появляется через сложный и комплексный процесс.

Бесспорно, что постарение населения - это естественное демографическое явление, сопровождающееся проблемами и возможностями. Пожилой возраст характеризуется ростом различного рода заболеваний, что сказывается на способности людей данного возраста оставаться независимыми.

В зрелом возрасте у многих пожилых людей возникают значительные проблемы со здоровьем, сказываясь на их способности быть независимыми, требуя, в свою очередь, возрастающей потребности в адаптации общества к изменениям здоровья пожилых людей посредством принятия мер в части охраны здоровья и обеспечения активного участия их в общественной жизни страны.

В последние годы российским государством сделаны существенные инвестиции в здравоохранение. Однако они не позволили значительно улучшить ситуацию, поскольку не сопровождались масштабными и высокоэффективными организационными и финансово-экономическими мероприятиями. Отставание уровня развития здравоохранения России от уровня развитых стран значительно сильней, чем во многих других ключевых отраслях экономики. Все выше затронутые проблемы обусловили актуальность темы исследования.

Ключевые слова: демографическое явление, дисбаланс, инвестиции, здравоохранение, мероприятия, постарение населения, экономика.

\footnotetext{
* Статья подготовлена по результатам исследований, выполненных за счет бюджетных средств по государственному заданию Финансового университета
} 
Аналитико-демографические показатели Европы определяют наличие устойчивых тенденций постарения населения. Темпы роста населения старше трудоспособного возраста увеличиваются, что сказывается на общей демографической ситуации мирового значения. Сравнивая показатели 1993 года с прогнозными показателями 2025 года необходимо отметить, что удельный вес пожилого населения увеличивается вдвое, а в некоторых странах и более. Доля лиц старше 80 лет 1993 года определялась $3,9 \%$, по прогнозу 2025 год их значение составит $6,8 \%$, во Франции - 4,1\% и 6,3\%, в Италии - 3,6\% и 7,5\%, в Голландии - 3,0\% и 5,0\%, в Швеции $4,5 \%$ и $7,5 \%$, Швейцарии $-3,9 \%$ и $5,6 \%$ соответственно.

Данные ВОЗ характеризуют ситуацию по увеличению численности возрастного населения (80 лет и более) к 2050 году почти в четыре раза. По данным ООН общемировое количество населения старше трудоспособного возраста (старше 65 лет) составляет 143 млн. человек, а это 5,2\% от всего населения с 1955 года к 2025 году увеличится до 822 млн. и составит 9,7\% населения планеты.

По среднему сценарию прогноза демографических показателей к 2050 году доля лиц старше 60 лет в Болгарии увеличится до 40,2\%, Польше - 39,6\%, Чехии - 38,6\%, Италии - 38,6\%, Латвии - 37,3\%, Украина - 36,6\%, Литве - 36,2\%. В настоящее время отмечаются значительные темпы увеличения доли населения старше трудоспособного возраста и нашей стране.

С.И.Кузин отмечает «процесс старения населения затрагивает все сферы жизни и исследуется специалистами в области социальноэкономической и демографической статистики, социологии, демографии, геронтологии и других наук» [2].

Постарение населения сопровождается различного рода заболеваниями. Согласно статистическим данным заболеваемость у пожилого населения на мировом пространстве с 2010 по 2020 года увеличилась на 8,5\%. В исследованиях значится, что основной проблемой в части здоровья пожилого населения планеты являются неинфекционные заболевания. Однако, условия пандемии COVID-19 в настоящее время, свидетельствуют об обратной ситуации и в зону риска с высоким уровнем смертности, попали в основном люди старше 65 лет. Пока полной статистики по влиянию COVID-19 на смертность пожилого населения планеты нет, однако, промежуточные исследования характеризуют высокий уровень смертности от пандемии данной категории граждан, лиц с ослабленной иммунной системой с хроническими заболеваниями.

62-я сессия Европейского регионального комитета ВО3 (ЕРК ВО3) приняла Стратегию, и план действий в части поддержки здорового старения населения планеты на 2012-2020 гг. В Стратегии обозначены приоритетные прогнозные направления действий в части обеспечения:

- здорового старения посредством заботы о здоровье населения планеты на протяжении всей жизни человека;

- поддерживающей среды системы здравоохранения, в том числе длительного ухода за пожилым населением, приспособленной к потребностям такого населения;

- по укреплению базы фактических (статистических) данных;

- расширения научных исследований.

Примечательно, что данной стратегией предлагается приоритетные вмешательства (см. рисунок 1).

Также нельзя не остановиться на вспомогательных вмешательствах, связывающих вопросы здорового старения населения планеты с более широким социальным контекстом в части:

- предупреждения социальной изоляции, в том числе и социального отчуждения;

- жестокого обращения с возрастной категорией граждан;

- обеспечения должного качества ухода и др. за возрастной категорией граждан.

Постарение населения обусловлено процессом увеличивающим долю населения старше трудоспособного возраста в обще возрастной структуре как региона, так и сраны в целом. При этом выделяется два типа старения населения:

1-й тип. Старение населения сверху - процесс увеличение доли пожилых людей за счет увеличения продолжительности жизни населения, снижения смертности. Данный тип характерен, например, для Японии, Южной Кореи и других стран.

2-й тип. Старение населения снизу - процесс увеличение доли пожилых людей за счет увеличения только численности пожилых людей. Данный тип старения связан со снижением рождаемости. Данный тип характерен для Российской Федерации [1].

Таким образом, старение населения - это 


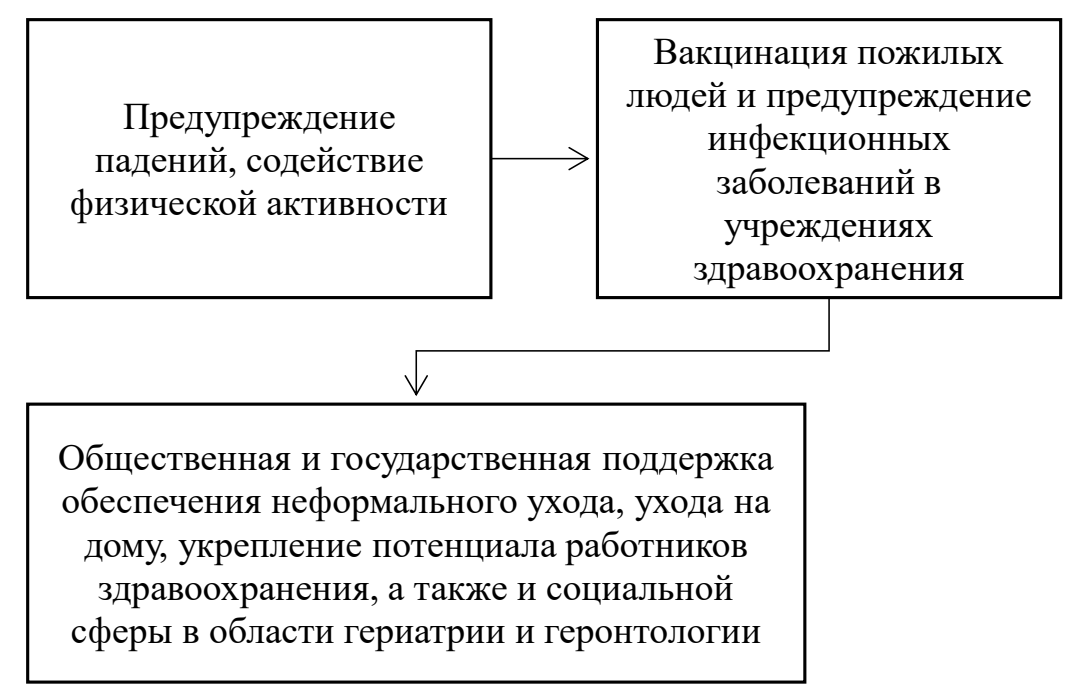

Рисунок 1. Приоритетные вмешательства стратегии направленной на поддержание здорового старения

естественный процесс, ему подвержены все страны мира, однако более всего он выражен в развитых странах.

Старение населения - это процесс, который зависит от следующих факторов:

а) рождаемость. Так, с увеличением рождаемости происходит омоложение населения страны, с ее уменьшением соответственно его старение;

б) смертность. Высокая смертность среди детей и лиц среднего возраста усиливают процессы старение населения страны, рост смертности среди лиц пожилого возраста тормозит данный процесс;

в) внешняя миграция, то есть приток мигрантов в страну из других стран, который чаще состоит их лиц молодого и среднего возраста, приводит к омолаживанию населения страны и тормозит процессы старения, отток мигрантов в другие страны усиливает процессы старения страны;

г) внутренняя миграция не оказывает влияния на процессы старения популяции в стране в целом, но может существенным образом повлиять на старение населения в конкретно населенном пункте, субъекте страны, регионе;

д) военные конфликты, которые ведут к безвозвратной потере населения страны чаще всего среднего возраста [6].

Однако, на фоне общего роста продолжительности жизни населения в Российской Федерации, необходимо отметить не самую благопри- ятную тенденцию к повышению доли пожилого населения по отношению к трудоспособному населению из-за снижения рождаемости и роста смертности в ряде регионов страны, и как следствие увеличения среднего возраста населения в нашей стране. «Так, если в 2009 году этот показатель был на уровне 38,8 лет, то на начало 2019 года он составил 40,2 по стране в целом» [4].

«Численность населения Российской Федерации в возрасте старше трудоспособного в 2018 году превысила 37 миллионов человек, или 25\% от общей численности населения» [5].

С другой стороны «пожилые люди вносят значительный вклад в общество в качестве официальных трудовых ресурсов и путем неформального труда, работы на добровольных началах и содействуя своим семьям» [3].

Представленные показатели свидетельствуют о продолжающейся тенденции старения населения, которая, скорее всего, будет и далее ухудшаться. Учитывая, что в стране в ряде регионов вырос возраст людей, вступающих в брак, рождение детей, кроме того, сейчас в возраст создания семьи входит малочисленное поколение 90-х - начала 2000-х годов, когда рождаемость в стране была крайне низкой, отмечается усугубление положения устаревания населения. Поэтому проблемы постарения населения и их приоритетная позиция в перечне проблем настоящего времени развития общества выходят на первое место и требуют серьезных и оперативных изменений. 


\section{Библиографический список}

1. Воронцов А. В.Демография: учебник и практикум для прикладного бакалавриата/ А. В. Воронцов, М. Б. Глотов.- М.: Издательство Юрайт, 2017.- 287 с.

2. Кузин С.И.Старение населения: социально-экономический аспект // file://D:/Users/Primary/Downloads/ starenie-naseleniya-sotsialno-ekonomicheskiy-aspekt.pdf (дата обращения 08.10.2020)

3. Москаленко В.Ф., Грузева Т.С. Современные медико-социальные проблемы старения населения и подходы к их решению // https://cyberleninka.ru/article/n/sovremennye-mediko-sotsialnye-problemy-stareniyanaseleniya-i-podhody-k-ih-resheniyu (дата обращения 30.04.2020).

4. Нацпроекты. Назван средний возраст россиян https:/lenta.ru/news/2019/09/12/age.

5. Распоряжение Правительства Российской Федерации от 14 апреля 2016 года № 669-р «Об утверждении плана мероприятий по реализации в 2016-2020 годах Концепции демографической политики Российской Федерации на период до 2025 года» [Электронный ресурс].- Режим доступа: URL: http://static.government. ru.

6. Харченко Л. П. Демография: учеб. пособие для студентов вузов, обучающихся по специальности «Статистика» и др. экономическим специальностям. - 3-е издание, стер.- М.: издательство «Омега-Л», 2009. - 350 с.

7. Петров А.М. «КОНТРОЛЬ ЗА ДВИЖЕНИЕМ ДЕБИТОРСКОЙ И КРЕДИТОРСКОЙ ЗАДОЛЖЕННОСТИ» Современный бухучет. 2004. № 9. С. 38.

8. Карпова Т.П., Петров А.М., Горбаткова Г.А., Самарина Л.Б., ДашкинаГ.Г., Сидорова М.И., Сабанин Р.Л., СИтникова В.А., Листопад Е. Е. «БУХГАЛТЕРСКИЙ УЧЕТ В СФЕРЕ УСЛУГ» Учебник дЛя студентов высшего профессионального образования, обучающихся по специальности 080109 «Бухгалтерский учет, анализ и аудит» / Под редакцией М.А. Вахрушиной; Министерство образования и науки Российской Федерации, Федеральное государственное учреждение «Федеральный институт развития образования». Москва, 2011. Сер. Читай

9. Петров А.М., МеЛьниковаЛ.А. «ФОРМИРОВАНИЕ ОТЧЕТНОСТИ В СООТВЕТСТВИИ С ТРЕБОВАНИЯМИ МСФО КАК ОБЪЕКТИВНАЯ НЕОБХОДИМОСТЬ НА СОВРЕМЕННОМ ЭТАПЕ РАЗВИТИЯ ЭКОНОМИКИ РФ» Проблемы современной экономики. 2017. № 2 (62). С. 105-107.

10. Петров А.М., Коняхин А. Н. «УЧЕТНАЯ ПОЛИТИКА ПРИ ПОДГОТОВКЕ ПЕРВОЙ ОТЧЕТНОСТИ СОГЛАСНО МСФО» Международный бухгалтерский учет. 2013. № 11 (257). С. 2-15.

11. Петров А.М., ЛЫмарь М. П. «СОСТАВ БУХГАЛТЕРСКОЙ ОТЧЕТНОСТИ В РОССИИ И КИТАЕ» МежДУНароднЫЙ бухгалтерский учет. 2014. № 31 (325). С. 28-37.

12. Петров А.М., ЛЫМарь М.П. «СРАВНИТЕЛЬНАЯ ХАРАКТЕРИСТИКА ОСНОВНЫХ ПОЛОЖЕНИЙ ЗАКОНОВ, РЕГУЛИРУЮЩИХ БУХГАЛТЕРСКИЙ УЧЕТ В КИТАЕ И РОССИИ» МеждУНароднЫЙ бУхгалтерскИЙ учет. 2013. № 40 (286). C. 52-60.

13. Петров А.М., ЛЫмарь М. П. «СРАВНИТЕЛЬНЫЙ АНАЛИЗ БУХГАЛТЕРСКОГО УЧЕТА АКТИВОВ В РОССИИ И КИТАЕ» Международный бухгалтерский учет. 2014. № 27 (321). С. 34-48.

14. Петров А.М. «ОБЩЕСТВЕННОЕ ПИТАНИЕ 6 в 1: учетная политика, документооборот, калькулирование себестоимости, бухгалтерский учет, налоги, отчетность» / А. М.Петров. Москва, 2011. Сер. Полное руководство бухгалтера 